\title{
As condições de desenvolvimento de um aluno com deficiência na escola pública.
}

\author{
Fabiana K. G. Urbano.
}

\begin{abstract}
Resumo
Este trabalho tem como objetivo discutir as condições de desenvolvimento de um aluno com deficiência numa escola da rede municipal de Campinas/SP. Com base nos autores da perspectiva histórico-cultural, principalmente Vigotski, e nas atuais políticas públicas sobre a educação especial, foi realizada uma pesquisa participativa em que a pesquisadora acompanhou - de uma a duas vezes por semana- uma professora e um aluno com deficiência múltipla, inserido no contexto da sala de aula. Foram utilizados na pesquisa empírica registros em diário de campo e videogravações semanais. A análise dos dados evidencia a importância das interações como lugar de desenvolvimento do aluno com deficiência e da prática da professora que envolve as crianças da turma. A pesquisa deu visibilidade aos modos de participação do aluno na dinâmica da aula, apontando tanto para o seu potencial quanto para as possibilidades que podem ser criadas nas formas de organização do trabalho pedagógico. Problematiza, por outro lado, as reais condições de trabalho na sustentação constante e necessária desse aluno na sala de aula. Os resultados indicam ainda a premência das condições de acolhimento e apoio institucionais, com o respaldo do poder público para a realização do trabalho da equipe escolar.
\end{abstract}

\section{Palavras-chave: \\ Educação escolar pública, desenvolvimento humano, deficiência múltipla.}

\section{Introdução}

Considerando-se que ao longo da história da pessoa com deficiência as formas de atendimento educacional foram sendo modificadas com a formulação de novas políticas públicas, e tendo em vista a atual proposta da educação especial na perspectiva da educação inclusiva, este trabalho tem como foco o desenvolvimento do aluno com deficiência no contexto escolar. O objetivo é, portanto, investigar as condições de desenvolvimento de um aluno com deficiência múltipla em uma escola da rede pública do município de Campinas/SP. Para tanto, este estudo se ancora na abordagem histórico-cultural, especialmente nas contribuições de L.S Vigotski sobre a sociogênese do desenvolvimento humano, as relações de ensino, o modo de conceber a deficiência, a plasticidade do cérebro e a complexidade do sistema funcional, bem como as questões metodológicas que privilegiam o estudo de processos em (trans)formação ${ }^{1}$.

\section{Resultados e Discussão}

Foi escolhido para acompanhamento o caso de um aluno com deficiência múltipla, ingressante no primeiro ano do ensino fundamental. $\mathrm{O}$ aluno tem sido acompanhado por uma equipe médica, que suspeita de uma possível ataxia cerebelar. Ele tem seis anos, é usuário de cadeira de rodas, tem baixa visão, não tem o controle dos movimentos, apresenta rigidez na motricidade orofacial, mas não fala e os movimentos de lábios e língua são frequentes e descoordenados. Frequenta a escola de duas a três vezes por semana e é acompanhado por uma cuidadora e pela professora de educação especial.

A pesquisadora realizou visitas semanais à escola escolhida para participar do estudo e utilizou como instrumentos de registro os diários de campos e as videogravações.

Das análises dos registros destacamos duas situações nas quais se mostram diferentes relações e modos diferenciados de participação do aluno na dinâmica das interações em sala de aula.

Primeira situação: contação de história por uma das pesquisadoras. As crianças estão sentadas no chão, em semicírculo. A professora senta-se também no chão e pede à cuidadora que retire o João da cadeira de rodas e o coloque em seu colo. Durante a contação da história com fantoches e outros objetos, ele movimenta, sutilmente, uma das mãos. Num momento de surpresa com um fantoche de Lobo e o grito assustado das crianças, a professora acalma a turma preocupada com os espasmos corporais do menino e o aconchega mais próximo de si.

- O gesto da professora mostra, ao mesmo tempo, a preocupação com a participação do aluno e a proteção a ele.

Segunda situação: João chega a escola uma hora depois do início das aulas. A professora pede para a cuidadora ler com ele a história do livro que tinha acabado de ser trabalhada com a turma. A cuidadora começa a folhear o livro e aponta para as imagens dos animais, nomeando-os. A pesquisadora que estava ao lado observando, coloca a mão de João na imagem da onça e diz "Olha João o desenho da onça no livro. Esse é um animal muito feroz né. Agora ela tá tirando um cochilo". A pesquisadora solta a mão de João e, sem ajuda, ele faz o mesmo movimento motor colocando e passando a mão na página do livro onde havia a figura da onça.

- Destaca-se a preocupação da professora em possibilitar a vivência do aluno em uma mesma atividade realizada com a turma; os modos de convocar o aluno para a leitura, da cuidadora e da pesquisadora; a realização conjunta do gesto de explorar o livro; o potencial de resposta do aluno.

\section{Conclusão}

As análises indicam:

- as possibilidades de participação e resposta do aluno com deficiência múltipla na interação;

- a importância do planejamento e da organização do trabalho pedagógico, de maneira que todos os alunos atuem de forma ativa sem deixar de considerar o desenvolvimento do aluno com deficiência;

- a necessidade de se atentar para as condições de trabalho da professora e a premência, ainda, de definição e implementação de políticas públicas que viabilizem o trabalho pedagógico.

1 COLE, Michel (org.); VIGOTSKY, L. S. A formação social da mente: o desenvolvimento dos processos psicológicos superiores.. 